\title{
Popüler Kültüre Bakarken Gündelik Hayatı \& Mikro Direnç Pratiklerini Görmek
}

\author{
Erhan Özcan ${ }^{1}$
}

\begin{abstract}
öz
Popüler kültür hegemonik değerleri yansıtan, yeniden üreten semiyotik kodlar ve ideolojik değerlendirmelerle yüklüdür. Bu metinler hâkim sınıfın hegemonik iktidarı ve buna dönük meşruiyetin üretilmesi için işe koşulur. Bu durum her zaman için gündelik yaşam ve pratikleri içerisinde gerçekleşir. Rıza üretim süreçlerinin kaldıraçlarından biri olan popüler kültür, her zaman için yönetici sınıfın hâkim anlam dünyasının temsil ettiği ve kendisini evrensel düşünceler, kategorilermiş gibi sunduğu anlam ve değerleri konsolide etmeye hizmet eder. Rıza üretimi okul, aile vb. kurum ve pratikler yanı sıra popüler kültürün gündelik olarak alımlanması içerisinde/dolayımıyla gerçekleşir. Ne var ki hâkim anlamları içeren kodların niyet edilen biçimlerde okunacağı ve istenilen tutum ve davranış değişikliklerine yol açacağı önceden garanti edilemez. Popüler kültürün konuşlandığı tüketim uğrağı ideolojik mesajların ters yüze edilerek, 'müzakereci' ya da 'muhalif', farklı okuma biçimleri ve karşıt anlam üretimiyle sonuçlanma potansiyeli taşır. Alternatif anlam üretimi içerisinde ortaya çıkabilecek anlam ve değerler, dünyayı egemen sınıfların gördüğü ve alt sınıfların da benzer şekilde görmelerini ve değerlendirmelerini arzu ettikleri biçimlerden ayrışır. Görme biçimlerinin değişmesiyle birlikte, direniş pratiklerinin mayalanma ve politik eyleme taşınma olasılığı hesaba katılmalıdır. Bu çalışmada popüler kültür gündelik hayat, ideoloji ve mikro direnç pratikleriyle olan ilişkisi içerisinde ele alınmaktadır. Araştırma nitel ve betimleyici bir çalışmadır. Bu çalışmada literatür taramasından yararlanıımıştır.
\end{abstract}

Anahtar Kelimeler: Kültür, Gündelik Hayat, Popüler Kültür, İdeoloji, Direniş.

\section{Observing Everyday Life \& Micro-Level Resistance upon Looking into Popular Culture}

\begin{abstract}
Popular culture can be defined in various ways. One of these definitions conceptualizes the popular culture in relation to ideology. In this perspective, the popular culture takes a form that basically helps transmitting dominant meanings as part of wider power relations. TV series, movies, works of art, belles-lettres, online contents, pop music and theater plays all serve to represent, mediate and diffuse ways of particular, dominant world images to social sphere. Popular texts incorporate semiotic codes and ideological evalutions that are subservient to dominant class. Bourgeoise mainly harnesses these texts to control and maintain social system. Ruling class also works through it with an ultimate aim to manifacture consent towards its rule. Accordingly, popular culture operates as a social leverage to consolidate system of dominant
\end{abstract}


meanings and values that seek to represent themselves as universal forms. Besides of schooling, parenting and as such, processes of consent-manufacturing always transpire in and by way of everyday reception practices. Nonetheless, codes that are laden with dominant meanings can always be counterproductive. These messages cannot automatically ensure behavioural changes. Instead, in terms of social consumption of meanings, we should take into account of negotiant or oppositional interpretations of dominant messages. Acts of different readings and alternative meaning-making can subvert hegemonic ways of observing the world, and potentially replacing them with oppositional ones. It, therefore, can help us creating a shift in the ways we perceive and understand the social phenomena. With potential shifts in our ways of observation, acts of resistance may always come into play that is then potentially prone to display of political acts. This study as a method of inquiry adopts qualitative research and applies descriptive approach. It accordingly draws on literature review.

Keywords: Culture, Everyday Life, Popular Culture, Ideology, Resistance. 


\section{Giriș}

"Popüler" terimi farklı anlamlar içerir ve toplumsal anlam üretimiyle damıtılmış çeşitli tanım çerçeveleriyle tanımlanır. Bunlardan belki de en bilindik olanı popüler kültürü insan toplumları tarafından gündelik yaşam pratikleri içerisinde, farklı kullanım ve doyumlar yoluyla deneyimlenen bir kavram olarak tanımlar. Buna göre popüler kültür, pek çok insan tarafından sevilir ve beğenilir. Populus'un, bir dereceye kadar ortaklaşan, beğeni ve zevklerini yatay keser; hemen herkes onda kendisini ifade edebileceği, özdeşlik kurabileceği bir şeyler bulabilir. Bu tanım esasında popüler kültür ürünlerinin, toplumsal sınıf, cinsiyet, kimlik ve dinsel aidiyet benzeri özne konumları fark etmeksizin, insanlar tarafından yaygın olarak kabul görmesini ve onaylanmasını ifade eder. Bir örnek vermek gerekirse; pek çoğumuz Godfather serisini izlemiş, beğenmiş ve üzerine hararetli sohbetler yapmışızdır. Kimilerimiz, daha da ileri gidip Godfather serisini oluşturan filmleri satın almış, DVD dolabının en görünür ve müstesna köşesini bu popüler kültür ürünü için ayırmıştır. Godfather koleksiyonu hiçbir zaman muhafaza edildiği köşesinde inertiye itilmemiş; arkadaş ya da dost buluşmalarında sembolik olarak harekete geçirilip yeniden üretilmek ve tüketilmek üzere başucumuzda beklemiştir. Hemen herkes Godfather serisini izlerken özdeşleşebileceği bir şeyler bulmuştur. Bu ünlü yapım, bir popüler kültür ürünü olarak pek çoklarımızın beğeni eşiğini katetmeyi başarmıştır.

Bir kültürel ürün popüler olabilmek için "sayısal bilgiye intiyaç duyar" (Hinds, 2006: 364), yani ürünün popülaritesi sayısal bilgiyle ölçülür. Bu manada, verili bir kültür ürünün tüketimine dair her birim miktar ve tüketim sıklığı benzeri niceliksel öncüller önem taşır. Storey'in (2009: 5) ifade ettiği gibi kitap satış oranları, CD veya DVD satış rakamları, konser, spor karşılaşmaları ve festivaller benzeri etkinliklerde satılan bilet sayısı, televizyon içeriklerinin izlenme oranları ve çevrim içi ortamlarda görülen izleyici etkileşimiyle birlikte açığa çıkan istatistiki verileri dikkate alııız. Klasik tedarik (supply), besleme modelinin (endüstriyel üretim) ihtiyaç duyduğu ölçme ve değerlendirme stratejileri ve bunun sonucu olarak elde edilen temsili sayısal bilgi, popüler kültürü anlamlandırmak açısından gerekli verileri şüphesiz ki sunar. Nominalistlerin gösterdiği gibi işaretler (sayısal, kavramsal) bize basit biçimde maddenin özünü verebilir. $\mathrm{Ne}$ var ki salt sayıların, istatistiklerin diline dayanarak yürütülen bir bilgi üretim faaliyeti, maddenin göstermediği imleri, spesifik bağlamları (tarihsel geçmiş ve şimdi) ve canlı insan faaliyetinin dinamiklerini anlamamı/anlamlandırmamız noktasında yetersiz kalır.

Popüler kültürün yukarıda tartışılan hâkim tanımı bize onun iki ana değişken dolayısıyla popüler olduğunu anlatır: İlk olarak, popüler kültürün söz konusu anlamlandırılma biçimi sıradan insanın gündelik epistemolojik süreçlerine yer etmiştir. Ortak imgelem popüler kültürü benzer şekillerde anlar ve anlamlandırır. Bu hususta, popüler kültür sadece yüksek teoriyle sınırlanamaz; akademinin, entellektüel faaliyetin sınırlarını aşarak toplumsal bilinçyapısına yer etmiştir. İkinci olarak, akademik söylemin popüler kültüre dönük tanım çerçevesi onu beğeni düzeyleri ve tercihlerle ilişkilendirmekte, popüler kültürün toplumsal olduğunu anlatmaktadır. Williams'ın (1983: 237) popüler olanı açımlamada kullandığı tanımlamalardan birisi olan "çok sayıda insan tarafından beğenilen, hoşlanılan” önermesiyle desteklenebileceği gibi, popüler kültür popülerdir. Popüler kültürün popülerliği Fiske'in (1989) deyişiyle verili kültür yapısının popüler zevklere hitap edebilmesi ve popüler olanın doğrudan halkı işaretlemesiyle ilgilidir. 
Dolayısıyla, bir kavram ve dilbilgisel işaret olarak "popüler", "kültür"ü niteleyerek onu semantik olarak önbelirler. Popüler terimi yine de kendi içinde başka kavram ve anlamlara işaret edebilir ve toplumsal, kültürel bağlamlarla iç içe geçer.

Popüler kültür kavramına dair ufkumuzu bu noktaya kadar anlatılanlarla sınırlı tutmak eksik bir bakış açısı olur. Popüler kültür kavramı nicel bilgiden, pazar araştırmalarından, izlenme oranlarından ve etkileşim miktarından fazlasını ifade eder. Bu anlamda, popüler kültürün ne'liğine ve nasıl'lığına açıklama getiren belli başlı yedi tanımlamadan bahsedilebilir. Yukarıda da gösterilmeye çalışıldığı gibi, bunlardan ilki ve en yaygın olarak kullanılanı popüler kültürü ortaklaşan, benzer insan beğenileri ve zevk örüntüleriyle ele alan tanımdır. Buna ek olarak, popüler kültürü anlamada ve açıklamada kullanılan altı farklı tanımdan bahsedebiliriz. Storey'e (2009: 5-13) göre bunlardan ilki popüler kültürü izah ederken onun "yüksek kültür"le olan ilişkisini önceleyen, önemseyen yaklaşımdır. Matthew Arnold ve F. R. Leavis gibi yüksek kültür teorisyenlerinin öncülük ettiği bu yaklaşıma göre popüler kültür, yüksek kültür ya da "elit kültür"ün içermediği, dışarıda kalmış reziduel bir kategoridir. Popüler kültür, hiyerarşik olarak, "yüksek kültür"ü ifade eden standartları karşılamada başarısız olmuştur ve bu nedenle "alçak kültür" olarak görülmelidir. Bu anlatıma göre popüler kültür sıradan, bayağı, basit, gündelik olanı anlatır ve toplumsal kültürün çöküşünden sorumludur. Yüksek kültür ürünlerinin aksine, kullanıcısını eleştirel düşünceye itmez, ondan kullanıcısına kendisini gerçekleştirmede katkı sağlaması beklenemez. Popüler kültürü ikincilleştiren, önemsiz ve hatta kültürel yapı için tehditkâr gören bu tanım "kitle kültürü" ya da "ticari kültür" tartışmalarını etkilemiştir. "Kitle toplumu" kuramıyla birlikte gelişen "kitle kültürü" yaklaşımı Adorno, Horkheimer ve Marcuse gibi Frankfurt Okulu düşünürlerinin çalışmalarında görülür. Buna göre popüler kültür, ideolojik kontrol ve toplumsal manipülasyon işleviyle geniş kitleleri eleştirel düşünceden alıkoyarak adeta sersemletir. Birey kategorisi, bireyselleşme, kültür endüstrisinin (ticari televizyon, radyo yayıncılığı, reklam ve halkla ilişkiler endüstrisi ve sinema gibi) tekelci kapitalizmin tüketim ideolojisini yayan kültürel kodların saldırısıyla yok edilmektedir. Ticari, profesyonel kurumların hazırladığı kültürel ürünler, klasik endüstriyel tedarik mantığı içerisinde seri olarak üretilmekte ve kitlesel olarak dağıtılmaktadır. Kitle kültürü kuramının aksine kültürün insanlara yukarıdan dayatılmaktadığını iddia eden "halk kültürü" yaklaşımı ise, popüler kültürün insanların otantik halk kültürleri yoluyla aşağıdan türediğini söyler. Amerikalı antropolog Robert Redfield, tarihçi Jaques Revel ve Michel de Certau gibi isimlerin önemli katkılar sundukları bu yaklaşıma göre popüler kültür, çağdaş kapitalizme karşı sembolik protestolarıyla öne çıkan işçi sınıfı kültürüyle eş tutulur. Halk kültürü teorisyenleri popüler kültürün egemen kodlara karşı çıkan sembolik anlamlar ve deneyimler olarak görür. Halk kültürü yaklaşımının aksine, "hegemonya teorisi”ne bakıldığında ise karşımıza başka bir tablo çıkar. Hegemonya teorisiyle popüler kültürün ideolojik işlevine vurgu yapılır. Popüler kültürün bu tanımı temelde İtalyan Marsist düşünür Antonio Gramsci'nin çözümlemelerine dayanır. Bu yaklaşım daha genel olarak 1964'de İngiliz Richard Hoggart'ın Birmingham Üniversitesi bünyesinde kurduğu İngiliz Kültürel Çalışmalar geleneği içerisinde benimsenir. Bu yaklaşımın önde gelen isimlerinde Marksist kültür ve edebiyat kuramcısı Raymond Williams ve Jamaikalı kültür teorisyeni Stuart Hall'un dedikleri gibi kültür insanlara yukarıdan dayatılmaz. Ne ki popüler kültür halk kültürleri gibi halkın maddi pratikleri dolayımıyla da açığa çıkmaz. Popüler kültür daha çok hegemonik mücadelelerin bir parçası olarak tasarlanır. Buna göre, kültürel metinler, toplumsal gruplar tarafından müzakere edilerek farklı anlamlarla yeniden üretilmektedir. Bunun sonucunda ortaya 
çıkabilecek karşıt anlamlar ise direniş mekanizmasını harekete geçirecek alternatif, muhalif anlamlama pratiklerinin bir bileşeni olarak karşımıza çıkabilir. Popüler kültürün son tanımı, postmodernist yaklaşımla birlikte damıtılan ve güncel denebilecek akademik tartışmalarla ilişkili görülür. Bu tartışmalarda, postmodern kültürün gelişiyle birlikte, klasik manada popüler yani hâkim olarak ticari meta olan ve otantik kültürü işaretleyen unsurlar arasında bir ayrım yapılamayacağı dillendirilir. Aralarında Umberto Eco ve Jean Baudrillard gibi ünlü düşünürlerin yer aldığı bu düşünce hattına göre, artık otantik olanla ticari kültürü simgeleyen arasında gösterildiği gibi belirgin bir çatallaşmadan, katı bir ayrışmadan bahsedilemez. Örneğin, Luciano Pavarotti'nin 1994 tarihli Puccini's 'Nessun Dorma albümü dünya müzik listelerinde zirveye tırmanıp ticari hit haline gelirken, İtalyan tenor yüksek kültürün, modern operanın gelmiş geçmiş en etkili isimlerinden biri olarak kabul edilmektedir.

Bu çalışmada, günümüz tüketim toplumlarıyla birlikte akademik bir tartışma alanı olarak beliren "popüler kültür" kavramı ele alınmaktadır. Bu yapılırken; popüler kültüre gündelik hayat, ideoloji ve mikro direnç pratikleriyle olan ilişkisi içerisinde değinilecektir. Çalışma kapsamında, popüler kültürün ideoloji ${ }^{2}$ ile olan ilişkisi ve popüler kültür biçimlerinin tüketim pratikleriyle olan bağının serimlenmesi amaçlanmaktadır. Bu manada, bu çalışma betimleyici araştırma olarak görülebilir; temel ekseni kitle iletişim mesajları/kültürel metinler ve izleyici konumları ilişkisi doğrultusunda ilerler. Çalışma içerisinde Anglo-Sakson Kültürel Çalışmalar Geleneği'nin ortaya koyduğu "izleyicinin aktifliği tezi" savunulmaktır. Dolayısıyla, geçmiş teorik tartışmalar ışığında, izleyicinin kitle iletişim mesajları ve beraberinde taşıdıkları anlamları basitçe soğurmadıkları, mesajları hegemonik kodlar kadar müzakereci ve muhalif okumalarla da yorumladıkları gösterilecektir. Bu çalışmada veri toplama yöntemi olarak literatür taramasından yararlanılmıştır. Bu doğrultuda, İngiliz (Stuart Hall gibi) ve Amerikan Kültürel Çalışmaları (John Fiske gibi) içerisinde kültürel metinler/popüler kültür, ideoloji ve alımlama ilişkisi üzerine odaklanan teorik tartışmalardan faydalanılmaktadır. Yanı sıra, bu tartışmalar üzerinde etki yaratan "hegemonya teorisi" ve Fransız düşünür ve antropolog Michel de Certeau'nun çalışmalarıyla anılan "strateji" ve "taktik" kavramlarına da yer verilecektir.

\section{$\mathrm{Bu}$ çalışmada popüler kültür, ideolojik imajların ve yorum çerçevelerinin içerisine}

2 İdeoloji kavramı popüler kültür teriminin anlaşılması için önemlidir. İdeolojinin farklı tanımları bulunur. Storey'in (2009: 2-5) gösterdiği gibi ideoloji ilkin, belirli toplumsal gruplar tarafından ifade edilen, sistematik olarak düzenlenmiş düşüncelerdir. Örneğin, belirli bir profesyoneller grubunun pratiklerini ifade eden düşünceler "profesyonel ideoloji" olarak tanımlanabilir. Ya da "Işçi Partisi'nin ideolojisi"nden bahsedebiliriz. İkinci olarak, "egemen ideoloji" olarak bilinen tezden söz edebiliriz. İdeoloji buradaki kullanımıyla belirli bir maskeleme, çarpıtma ya da gizleme işlevine göndermede bulunur. Kültürel metinleri ve pratikleri gerçekliğin çarpıtılmış imajları olarak sunar ve "yanlış bilinç" yaratır. Bu çarpıtmalar gücü elinde bulunduranların çıkarlarına hizmet eder ve güçüzlerin kendi çıkarlarını görmekten alıkoyar. Buna bir örnek kapitalizmin ideolojisi ya da "kapitalist ideoloji”dir. İdeolojinin bir diğer tanımına göre "ideolojik formlar" söz konusudur. İdeolojinin bu tanımı ideolojinin bir önceki tanımıyla ilișkilidir. Buna göre ideoloji, metinlerin (televizyon yapımları, pop müzik, romanlar, sinema filmleri vb.) her zaman dünyanın belirli bir imajını sunar. Bu tanıma göre "toplumsal" uzlaşmacı olmaktan çok çatışmacıdır ve eşitsizlik, sömürü ve baskı üzerine kurulmuştur. İdeolojinin dördüncü tanımı, Fransız kültür teorisyeni Roland Barthes'ın erken dönem eserlerine dayanır. Barthes ideolojinin (ya da kendi deyişiyle 'mitler') temelde yan anlamlar düzeyinde, ikincil ve sıklıkla bilinçdışı anlamlar olarak işler. Bu anlamlar metinler ve pratikler dolayımıyla taşınır ya da taşıyacak șekilde üretilir. İdeolojinin son tanımı bir bașka Fransız düşünür Althusser'den gelmiştir. Althusser'e göre ideoloji, bireylerin gerçek varoluş koşullarıyla kurdukları imgesel ilişkidir. Bu ilişki hayali olsa da ideolojik aygıtlar içerisinde görünür ve maddi pratikler yoluyla işler. Bu tanıma göre ideoloji, bireylerin içerisinde yaşadıkları nesnel koşullarla kurdukları bir temsil ilişkisidir. İdeoloji öznelerin maddi pratikleri yoluyla ideolojik aygıtlara katılmalarıyla kurulur ve yeniden üretilir. Althusser bu aygıtları "Devletin İdeolojik Aygıtları" (DIA) olarak adlandırır. Bunlar; aile, din, medya, sendikalar, hukuk sistemi ve diğer başka DiA'lardır. 
iliştirilerek toplumsala dağıtıldıkları "ideolojik biçimler" (ideological forms) (Marx, 1998) olarak anlaşılmaktadır. Bu biçimlerden başlıcaları; televizyon yapımları, reklam içerikleri, radyo programları, sinema filmleri, tiyatro oyunları, sanat yapıtları, romanlar, karikatür ve moda dergileri benzeri, geniş bir semiyotik sistemin parçalarını, tamamlayıcı öğelerini oluşturan fakat aynı zamanda, hâkim semiyotik kodları toplumsal sinir yapısına taşıyan ve bu mesajları dolayımlayan ürünlerdir. Popüler kültür ürünleri egemen ideolojinin ifadeleridir, tıpkı Voloşinov'un (1930: 10) belirttiği gibi gerçekliğin parçası olmayıp, başka bir gerçekliği yansıtır ve kırılmaya uğratır. Bu metinler her zaman ideolojik değerlendirme ölçütleriyle yapılandırıırlar. Bu değerlendirmeler yansız ya da tarafsız değildir. Bize bir şeyin doğru, yanlış, adil ya da iyi olup olmadığını anlatır Bu sembolik ürünler ve pratikler Hall'un (1981: 122-123) söylediği gibi kolektif anlayışın üretildiği bir alanı oluşturur ve burada anlamlama politikaları devreye girer. Söz konusu politikalar insanların dünyayı görme biçimlerini belirli biçimlerde üretmeye, bu biçimleri telkin etmeye çalışmaktadır. Kültürel Çalışmalar Geleneği'nin İtalyan düşünür Gramsci'nin "hegemonya teorisi"nden etkilenerek ortaya koyduğu gibi, ideolojik olan ya da ideolojiyi oluşturan toplumsal konfigürasyonun kendisi sadece ideolojinin üretimi ve egemen anlamların kurumsallaşmasını anlatmaz. Bu aynı zamanda toplumsal, sembolik bir mübadele, müzakere ve mücadele alanıdır. İktidarın ideolojik söylemlerinin nesnesi olarak sosyalize edilmeye uğraş verilen, kitlesel manipülasyona maruz bırakılan ve bu manada psikolojik olarak baskılanan madunlar ${ }^{3}$ (örneğin propaganda süreçleri yoluyla), yani Spivak'ın (Spivak 1988'den aktaran Gandhi, 1999: 1) deyişiyle genel olarak düşük, alt (inferior) toplumsal konumların taşıyıcıları egemen anlamları basitçe pasif olarak tüketip kabullenmez. Herşeyden önce, ideolojik değerlendirmeleri dolayımlayan, yeniden üreten kültürel metinler salt üretim uğrağından geçmeyip tüketilir. Kitle iletişim medyası tarafından üretilen ve dolaşıma sokularak toplumsal söyleme dâhil edilen bu metinler, farklı bağlamlarda, farklı kullanım/tüketim biçimleriyle alımlamada bulunan izleyici gruplarıyla karşılaşır. Bu anlamların kimileri egemen söylemle uyumlu olacak şekilde yorumlanıp kabul edilir. Ne var ki kimi anlamlar ıskalanır, kişi niyet edilen ideolojik mesajları yakalayamayabilir. Kimi anlamların üzerinden atlanır, kimileriyle ise ilişki dahi kurulmaz. Alımlayıcı kendisini medyatikleşen toplumsal yaşamla birlikte zaman ve mekâna yayılan anlatılara kapatabilir. Bazısı alımlamaya koyulduğu metinden orta yerinde vazgeçer, mesajdan haz duymadığını farkeder. Bazen de öfkelenerek aynı mesajı alımlamaktan vazgeçer; alımlama alışkanlığını değiştirebilir. Kimi zaman ise egemen söylemlerle niyet edilen anlamlar etkisizleştirilir; anlatı kısmen ya da topyekûn olacak şekilde hedefinden saptırılır.

İdeolojik değerlerin ve kolektif anlam üretimi süreçlerinin filtresinden doğru süzülen anlamlar, bireylerin öznel iradeleri, kolektif anlamların toplumsal müzakeresi ve en sonunda da direniş pratikleriyle karşılaşmaksızın var olmaz. Söz konusu süreçler belirli bir toplumsal bağlama ve bu bağlam içerisinde çoğunlukla ayrışan ama aynı zamanda benzerlik taşıyan kültürel pratik ve deneyimlere intiyaç duyar. Bu hususta, gündelik yaşam öne çıkar ve önem kazanır. Popüler kültürün üretimi, dolaşımı ve deneyimlenme biçimleri gündelikli olan, sıradan bağlamların içerisinde açığa çıkar. Bu bağlamlar; farklı

3 Madun (subaltern) kavramı ilk kez İtalyan düşünür Antonio Gramsci tarafından kullanılmış ve kavramsallaştırılmıştır. Gramsci (1971) madun kavramını burjuva sınıfın ahlaki ve entellektüel liderliği altında, yani hegemonyası altında yönetilen proleter ve köylü sınıfları nitelemede kullanır. Kavramı Güney Asya toplumları özelinde (özellikle Hindistan) kullanan Hintli tarihçi ve "Madun Çalışmaları Grubu" temsilcisi Ranajit Guha (1988: 283) madunları, iktidarın boyun eğdirme ve baskılama politikalarına maruz kalan toplumsal gruplar olarak tanımlar. Madunlaştırma kendisini toplumsal sınıf, cinsiyet, kast, yaş ve meşru otorite (makam) dolayısıyla gösteren pratiklerdir. 
özneler, özne konumları, çeşitlilik gösteren pratikler ve deneyimlerin kesişiminde yer alan gündelik hayat sorunsalına işaret eder. Dolayısıyla, ideolojik değerlendirmeleri taşıyan, ifade eden popüler kültür alanı; metinlerin alımlanması, yani tüketim uğrağı olmaksızın işlerlik kazanmaz. Farklı özne konumlarına, ilgi, beğeni ve hazlara sahip alımlayıcılar, popüler kültür içerikleriyle kitle iletişim medyasının dolayımlayıcılığıyla karşılaşırlar. Bu temaslar sonucunda niyet edilen anlamların tüketimi hiçbir zaman garanti edilemez; alımlayıcılar mesajlara ve ideolojik anlamlara direnç gösterebilir. Tüm bunlar belirli bağlamların içerisinde gerçekleşir; bu sıradan, rutin ve tanıdık oluşuyla gündelik yaşamın ta kendisidir.

$\mathrm{Bu}$ çalışmanın ilk bölümünde gündelik hayat ve kültür ilişkisine yer verilecektir. Popüler kültürü anlamak için öncelikle kültür kavramına bakılmalıdır. Kültür zorunlu olarak gündelik hayatın içerisinde var olur ve mikro düzey pratik ve öznel, toplumsal deneyimler dolayısıyla dışa vurulur, yaşantılanır. Yine bu bölümde kültür süreçlerinin, toplumsal kültürü yansıtan, gösteren maddi insan faaliyetinin gözlem yoluyla anlaşılabileceği tartışılacaktır. Çalışmanın ikinci bölümünde ise popüler kültürün diyalektik ve çatışmacı bir dizi süreç sonucunda üretildiği; makro-mikro diyalektiğinin popüler kültürü anlamlandırmamızda zorunlu olduğu dile getirilecektir.

\section{Gündelik Hayat ve Kültür: Kültürel Süreçlerin Bilgisine Erișebilir miyiz?}

Tekeli'nin (2000: 42) belirttiği gibi gündelik yaşam dediğimizde genellikle toplumdaki bireylerin günlük zaman bütçesi içerisinde yer tutan beslenme, giyinme, barınma, uyuma vb. faaliyetlerini anlıyoruz. Bu faaliyetler yapılırken yiyecekler, giyecekler, ev eşyaları vb. özel nesnelerin kullanıldığını biliyoruz. Gündelik yaşam pratikleri, bu pratiklerin bilgisi, yapıp etme biçimleri ve bir şeyler yaparken kullandığımız nesneler bütün olarak gündelik yaşamın kültürel çevrimini oluşturur. Yinelemeli bir toplumsal döngüye işaret eden bu tür bir çevrim; bireyler açısından sıradanlığı, doğalığı, sadeliği, rutinliği, tanıdıklığı, konforu, ontolojik güven duygusunu ve en nihayetinde de yerleşik olanı niteler. Bireylerin günlük yaşam faaliyetleri, bu faaliyetlere yatırılan zaman bütçeleri ve bu faaliyetlerin taşıyıcıları (biz failler) şimdi ve buradalığa demir atar. Gündelik yaşam dünyevi olanda köklenir, dünyevi olanı simgeler ki bu onun seküler olduğunu da gösterir. Feltski'nin (2000: 16) ifade ettiği gibi gündelik yaşam, aşkınlık/kutsallık bağlarından silkinmiş; ruhani/manevi dünyayla olan ilişkisini koparmıştır. Bu rutinlerin toplumsalla kurduğu bağ (siyasi, kültürel, ahlaki, kan ya da hukuki bağlar benzeri ortak olarak paylaşılan) gündelik yaşama demokratik olma özelliği kazandırmaktadır. Gündelik yaşam, birlikte, becerebildiğimiz kadarıyla bir arada var ettiğimiz maddi süreçlere gömülü olması ve dünyevi olanın ne'liğine dair ortak bir kavrayışa sahip olmamız nedeniyle demokratiktir. Gündelik yaşamın ya da gündelik(li) olanın (quotidian) kuşatamadığı, kapsayamadığı ya da içerisine sızmadığı hemen hiçbir şey yoktur. Herkesin yaşamı az ya da çok gündelikli olandan bir parça içermekte, bir yanıyla da olsa, gündelik yaşama değmektedir.

Gündelik olan her ne kadar toplumsal yaşamı kapsayıp, onunla içe içe geçse de, bu onun mikro düzeyde ayrışık, farklı ya da özgül olmaktan uzak bir totalite olduğunu göstermez. Gündelik yaşamın toplumsalın kılcallarına nüfuz ettiği doğrudur. Fakat bu toplumsalı gündelik yaşamdan ayrı düşünemeyeceğimiz anlamına gelmez. Aksine, gündelik yaşam bireylerin kişisel edimleri, bireysel tutum, davranış ve öznel yargıları 
doğrultusunda pratik edilir. Inglis'in (2005:3) kendi (akademik) kimliğinden yola çıkarak vermiş olduğu örnekle gösterdiği gibi, beyaz, orta sınıf ve görece imtiyaz sahibi bir akademisyen olarak yaşadığım gündelik hayatın kimi yönlerden işçi sınıfından gelen siyahi bir bireyin yaşadığı gündelik hayattan farklı olması kaçınılmazdır. Uyumak, uyanmak, beslenmek, güne hazırlanmak ve gün içerisinde bazı rutin faaliyetlerde bulunmak benzeri edimlerde ortaklaştığımız doğrudur. Fakat bu gündelik faaliyetlere dair ayrıksı yapıp etme biçimlerimizin olduğu gerçeğini değiştirmez. Başka bir şekilde söylemek gerekirse, her insanın işgal ettiği nesnel konumu zorunlu olarak farklılaşacaktır, tam da bu nedenle, her birimizin gündelik faaliyetleri gerçekleştirme biçimleri şu ya da bu ölçüde özgüllük taşıyacaktır. Bu farklılıkları, çatallanmaları ve özgüllükleri anlamak ve anlamlandırabilmek için toplumsalın ne şekilde yapılandırıldığı, bireylerin toplumsal yaşamlarını nasıl örgütledikleri ve bu doğrultuda ortaya çıkan gündelik davranış kalıplarının ne türden tezahürler gösterdiğini keşfetmemiz gerekir. Çünkü ancak bu şekilde toplumsal gerçekliğin ayrılmaz bir parçası olan gündelik faaliyetlerimiz (gündelik yaşama etki eden tüm ideolojik dolayımların ve anlam üretiminin) ve gündelik bağlamlar içerisinde neden şu ya da bu şekilde "davrandığımız hakkında daha çok şey bilmiş, daha çok şey bildikçe de gelecek yaşamlarımızı daha kolay biçimde etkileme imkânına sahip olabiliriz" (Subaşı, 2004: 24-25).

Lefebvre'in (1995: 16) gündelik yaşam rutinlerimizin bilgisiyle bağlantılı olarak vurguladığı gibi, gündelik hayatı kavramaya dönük her türlü çaba, toplumsal ilişkilere içkin çelişki ve çatışmaları anlayarak, bu çelişkilerle ortaya çıkan kolektif anlamlara ulaşmamızı sağlayacaktır. Aynı şekilde, böylesi özel bir çaba bize hâkim kültürü dönüştürebilmemiz açısından gerekli imkân ve araçları da sunma potansiyeli taşımaktadır. Bu çabanın somutlanmasının koşulu insan davranışları ve bu davranışları sembolik düzeyde anlamlandıran/aktaran dil sistemi, toplumsal normlar, değer yargıları, inançlar ve toplumsal bireylerin düşünme biçimleri benzeri öğelere bakmaktan geçer. Bu, tam da Inglis'in (2005: 4) dediği gibi bizi daha genel ve kapsamlı bir kavram olarak kültür kavramına götürecektir Kültür, diyalektik olarak, farklı toplumsal süreçlerle iç içe geçerken, bu süreçler de kültürün içerisine gömülmüştür. Kültür gündelik yaşam faaliyetlerimizi ve bu faaliyetlere dair bilgimizi yapılandırırken, her yeni günle birlikte kendini yineleyen gündelik yaşam faaliyetleri dolayımıyla da yapılandırılmaktadır.

Kültürel yapı insanların gündelik hayat faaliyetleri dolayısıyla imal ederek yaydıkları ve bu yolla, toplumsal yaşamlarını inşa edip devamlılığını sağladıkları semboller sistemi ve maddi pratikler bütünüdür. Bu manada zaman- mekân bağlamı ve kültürün icrasında kullandığımız nesneler devreye girer. İlkine göre, kültür denen şey belirli bir zaman-mekân bağlamı içerisinde inşa edilip yeniden üretilmektedir. İkincisine göre, kültürel sistem toplumsal grupların belirli bir zaman-mekân ilişkisi içerisinde olacak şekilde düşüncelerini, değerlerini ve inançlarını temsil eden, yapıp etme biçimlerine eşlik eden, dolayımlayan kültürel ürünlerle ilgilidir. Bu ürünler eşyalar benzeri maddi, somut şeylerden oluşabileceği gibi, sözlü ürünler benzeri soyut, gayri maddi biçimler de olabilir.

Toplumsal grupların sahip oldukları anlam ve inanç örüntüleri, bu grupların ürettikleri maddi ve gayri maddi ürünlerde cisim bulur; yaşar, yaşantılanır ve yaşatılır. Inglis'e (2005: 4-8) göre maddi ya da gayri maddi olsun bu ürünler doğaları gereği gelişigüzeldir, keyfi (arbitrary) bir karakter taşırlar. Bunlar, en nihayetinde, bilinçli insan faaliyetlerinin 
ürünleridir ve toplumsal yaşamı üreten, şekillendiren mekanizmalar olarak nesilden nesile aktarılır, öğretilir ve öğrenilirler. Kültürü oluşturan insan faaliyetleri Inglis'in (2000: 12-13) tartıştığı gibi toplumsal grupların kendi kimliklerini ve yaşam dünyalarını inşa etmesine, düşüncelerini, değerlerini ve inançlarını kısacası ne olduklarını ifade eden tüm öğeleri var etmelerine yardımcı olur. Toplumsal gruplar arasında değişkenlik gösteren düşünme ve hissetme biçimleri bize şu ya da bu gruba üye bireylerin belirli bağlamlarda ve belirli biçimlerde davranmaya dönük güdülerini gösterir. Aynı gruba mensup bireyler belirli bir bağlamda maruz kaldıkları kültürel, gündelik uyaranlara karşı benzer tepkiler vererek benzer davranış kalıpları sergiler. Kültürel davranışlar farklılaşan ama bir yandan da benzeşen davranış kalıplarını içereceği gibi, düşünsel pratikleri, alışkanlıkları, yapıp etme biçimlerini ve tüm bunların içerisine yazıldığı/ifade edildiği metinleri, hâkim, seçici gelenekleri de anlatır. Marksist kültürel çalışmalar geleneğinin önde gelen temsilcisi Raymond Williams'ın (1989: 93) dediği gibi kültür sıradan olandır. Bir bütün olarak yaşam biçimi olarak da görülebilir. Bunlar keşfetme ve yaratıcı faaliyetler sonucunda ortaya çıkan ortak anlamlar ve yorumlamaları, sanat, toplumsal iletişim süreçleri ve öğrenme benzeri öğeleri kapsar. Bu süreçler toplumsal ve tarihsel olarak oluşturulur ve canlı kültür, kaydedilebilir kültür ve seçici geleneğin kültürü olarak üç grupta değerlendirilebilir. Bunlardan ilki, yani canlı kültür, bir toplumsal grubun belirli bir durum hakkında ne düşündüğü, bu durum karşısında ne hissettiğidir.

Seçici geleneğin kültürü, yüksek kültür ve bu kültüre ait ürünlerdir. Kaydedilebilir kültür ise insanların nasıl düşündükleri, hissettikleri, sahip oldukları sanat ürünleri, gazeteler benzeri yazılı basın, kitle medyası ürünleri, bürokratik belgeler, kişisel günlükler ya da yazılı hatıratlar benzeri pek çok farklı belgeden oluşabilir. Inglis (2000: 12-13) kaydedilebilir kültürü temsil eden belgelerin toplumsal kültür süreçlerini gözlemlememiz ve kavramamız açısından önemli birer kaynak olduğunu söyler. Fakat Inglis'e göre bu artefaktlara karşı uyanık olmamız gerekmektedir. Birer veri olarak bu belgelerin bize canlı kültüre ulaşma, onu anlama ve anlamlandırma imkânını tanıdığı yadsınamaz. Ne var ki bunlara yerinde bir ihtiyat ve kuşkuyla bakmamız doğru olacaktır; çünkü bu ürünler üreticisinin kişisel yargıları ve bakış açısıyla oluşturulmuştur. Taraflı ve yanlı olmaları doğal ve kaçınılmazdır.

Inglis'e (2000: 13) göre canlı kültürü anlamak pek de kolay değildir; yoğun bir dikkat ve özen gerektirir. Bu hususta karşılaşacağımız en temel ve belki de en muhtemel sorun; üzerine kafa yorduğumuz araştırma öznesinin gündelik varoluş tarzına dönük algımızdan, kişisel eğilimlerimiz ve parçası olduğumuz akademik politikalardan bağımsız şekilde şekillenmesinin güç olduğudur. Toplumsal sınıf, etnik kimlik ve toplumsal cinsiyet benzeri özne konumlarımız, ideolojik eğilimlerimiz, değer yargılarımız, davranışlarımız, yani genel olarak kişisel ardyöremizi oluşturan tüm belirleyenler başkaları hakkında ne konuştuğumuzu belirleyecek ve onları değerlendirme biçimimizi etkileyecektir. Ayrıca, araştırmacının topladığı bilgiyle ne yapacağı, kendisinin akademik çevrede nasıl tanınmak/algılanmak istediği benzeri araştırmacının öznel istenç ve kaygılarını ifade eden süreçlerin de bilgi toplama ve yorumlama pratikleri üzerinde etkili olacağı kayda düşülmelidir. Buradan hareketle, böylesi bir keşif ancak toplumsal yaşamı yerli yerinde yapan gündelik pratikleri tam da görünür oldukları zaman-mekân bağlamı içerisinde özenle ve dikkatle seyrederek mümkün olabilir. Tanıdık olunan her zaman sıradan olanı, üzerine düşünülmeyeni, sorgulama dışı olanı işaretler. Inglis'in (2000: 8-9) dediği gibi sorgulama dışı olanın içinin açılarak ters yüze edilebilmesi için insanların yaşam dünyaları fark edilmelidir. 
Bu dünyanın düşündüğümüz gibi doğal olmadığı ve şeyleri yapıp etme yollarının farklılaşabileceğinin idrakine varılmalıdır. Bunu yapabilmenin yolu sıkı fakat maksatı ve bilinçli bir gözlem pratiğinden geçer. Sıradan olan göz hapsine alınmalı; sıradan olduğu kadar özel ve hatta sıradışı olduğunun ayırdına varılabilmelidir.

Inglis (2000: 11) bu türden bir gözlem pratiğini Fransız yazar Perec'in Paris'te sıradan bir günde, sıradan bir Paris kafesinde kahvesini yudumlarken kayda düştüğü deneyimiyle örneklendirir. Georges Perec Paris'in merkezinde yer alan bir kafede kahvesini yudumlamaktadır. Bu sırada kafenin yakınında bulunan bir marketten meyveli jöle almak için duran bir sürücüyü görür. Sürücü arabasını park etmektedir ve Perec adamın davranışlarına dikkat kesilir. Fransız yazar ilk bakışta herkes için malumun ilanını taşıyan detayları, yani sürücünün sıradan denilebilecek park etme eylemine dair davranışlarını ayrıntılarıyla not etmiştir. Sürücü, tıpkı tüm diğer akranları gibi, arabasını park edecek uygun bir yer aramaktadır. Bir süre sonra park yeri bulmuş ve kontak kapatmıştır. Anahtarını yanına almış ve olası bir çalınma riskine karșı arabasının güvenlik alarmını kurmuştur. Kapıların, sağ-sol sileceklerin ve el freninin kapalı ya da çekili olup olmadığını kontrol etmiştir. Sürücü bir süre sonra arabasından çıkabilmiştir. Perec yapmış olduğu bu gözlem sonucunda sıradan olanın aslında özgül ve kişiye özel olabileceğini fark etmiştir. Kendi gözlemi sırasında sürücünün arabasıyla kurduğu ilişkinin kişinin sahip olduğu kültürel varsayımları açığa çıkardığını fark etmiştir.

Öte yandan, araba sahibi olmak aynı zamanda toplumsal bir statü işaretidir. Arabası sahibi için gurur kaynağıdır. Kişi iyi huylu bir mizaca sahip olsa dahi trafikte zıvanadan çıkarak tüm sukunetini yitirebilir. Sürücülerin arabalarıyla olan ilişkileri dikkatli olmayan göze sıradan, bilindik eylemlermiş gibi gözükebilir. Fakat Perec'in gözleminin de gösterdiği gibi sıradan ve tanıdık olunan her şey karmaşık manevralar ve ritüellerden oluşmaktadır. Basit, sıradan bir park etme eylemi dahi kendine has bir sanata dönüşebilir. Bu noktada görüldüğü gibi tanıdık olanın yapı sökümü mevcut kültürel dolayımları ve bu dolayımların içerdiği bilme, ilişkilenme biçimleri ve alışkanlıklarını yüzeye çıkarmamıza yardımcı olacaktır. Yanı sıra, gündelik hayatın doğasında bulunan espirili yönleri deşifre etmemiz de kolaylaşacaktır. Bu maksatla temelde yapmamız gereken şey; arkamıza yaslanmak ve yaşam dünyasının gündelikliliğine içkin sıradanlığı dağıtacak bir bakışla gözümüzün önünde cereyan eden olaylara yoğunlaşmaktır. Bakış sahamızın orta yerinde açığa çıkan, zaman zaman çevreye saçılarak dağılan fenomenler, kültürün bedenlendiği, dikkatle bakanın algı duvarına çarpıldığı anlardır. Bu anların görüldüğü spesifik zaman-mekân bağlamlarını gözden kaçırmak, bize sunulanları, gösterilenleri gör(e)memek elbette her zaman için ihtimal dahilindedir. Buna karşın, titizlikle gerçekleştirilecek maksatı ve bilinçli bir gözlem, çevreye dağılan uyaranları yakalayarak dikkat yatırımının anlamlı bir bilgi üretim sürecine tercüme edilmesine yardımcı olacaktır. Kültürel süreçlere erişimimiz zaman ve bilinç yatırımını gerektirir. Buna bedensel ve duyusal oradalığı (thereness) dâhil etmek de mümkündür.

\section{Popüler Kültür, Toplumsal Anlam Üretimi ve Mikro Direnișler}

Toplumsal gerçekliğin düzenlenerek kurumsallaştırılması çabası Polanyi'nin "çifte hareket" (double movement) (2001) dediği şeyle belirlenir. Karl Polanyi "çifte hareket" kavramına kapitalist sistemin gelişim mekaniğini, kendi içsel mantığını açıklamada 
başvurur. Polanyi'ye göre kapitalizmin kurumsallaşması salt bu üretim modelinin taşıdığı içsel dinamiklar yoluyla olmamıştır. Laissez-faire düzeni devlet müdahalesi, kamu otoritesinin mülkiyet ilişkilerini hukuki yollarla düzenleyerek güvence altına alması benzeri biçimlendirici tasarruflarla da şekillenmiştir. Kapitalist sistem ya da "görünmez el" en bașından beri doğal, kendinden menkul, hiçbir aktör, dışsal uygulama ya da tazyik olmaksızın var olmuş ve gelişmiş değildir. Esasına bakılırsa toplumsal gerçekliğin kurumsallaşması ve biçimlenme mantığı da benzer bir çifte hareketle kurulur. Çifte hareketin bir yanı, yönetici sınıfların ellerinde tutukları iktidar yapılarının homojenize ve kuşatıcı edici etkisini seferber ederek, toplumsal katmanları kendi anlamları, çıkarları ve değerler sistemiyle uyumlulaştırmaya dönük uygulamalarını anlatır. Böylece, egemen sınıfların çıkarları güvence altına alınmış, toplumsal yeniden üretim gerçekleşmiş olacaktır. Buna karşın, bu anlamların ve değerler bütünün toplumsal katmanlarda potansiyel olarak müzakere edildiği veya toplumsal güç ilişkilerini yaratan, meşrulaştıran ve yeniden üreten bu sembolik dizgeye karşı karşı çıkılarak, farklı söylemler ve temsil biçimleriyle meydan okunduğu söylenebilir. Dolayısıyla, çifte hareket bir yandan egemen anlamların üretim ve dolaşımı, toplumsal iletişim yoluyla yönetilenler üzerinde uygunan psikolojik baskı, kitlesel manipülasyon benzeri mekanizmalardan oluşurken, yönetilenlerin egemen anlamlara getirebilecekleri muhalif okumalar, karşıt anlamların üretimi gibi örüntüleri de içerir. Bu bakımdan, toplumsal alanın ve güç mekanizmalarının rafine, karşıtlık ve gerilimlerden arındırılmış sosyal bir boşluk içerisinde devindiğini, biçimlendiğini söylemek mümkün değildir.

Kültür de kaçınılmaz şekilde toplumsal güç ilişkilerinin kesişiminde yer alır. Kültür, çifte hareketin ilk yüzüne ayna tutacak şekilde, Inglis'in (2000: 8) tariflediği gibi hâkim sınıfın ve toplumsal grupların düşünce ve hissetme biçimleri çerçevesinde belirlenir; kültürel örüntüler, hâkim toplumsal gruplar tarafından oluşturulan formel kurum ve gündelik pratikler aracılığıyla şekillendirilir. Kültür, bu yönüyle, hâkim sınıfların kendi fikir dünyalarını, değer ve inançlarını bağımlı sınıflara taşıdıkları, onlara kendi imajlar sistemini aşılamaya çalıştıkları bir ideoloji biçimidir. Örneğin, farklı diller (söylemler) sadece dünyayı farklı şekillerde tanımlamakla kalmayıp, hâkim grupların bağımlı gruplar üzerindeki çıkarlarını temsil edecek şekilde tanımlar. Kültürün iktidarla olan ilişkisi onun ideolojik bir endoktrinasyon, toplumsal kontrol ve denetim aracı olduğunu gösterir. Burada söz konusu olan; Adorno'nun belirttiği gibi (2009: 110) yüksek kültürün etkileri üzerinde spekülasyon yapılarak ciddiyetinin ortadan kaldırılması, düşük kültürün ise, toplumsal denetim bütünsel olmadığı sürece, barındırdığı haşarı isyankarlığın uygarlaştırıcı dizginlemeler yoluyla yok edilmesidir. Bu minvalde, modern toplumlarla birlikte popüler kültüre yüklenen ideolojik kontrol ve denetim işlevine değinmemiz icap etmektedir.

Gündelik yaşamı yapılandıran, onunla ilişki içerisinde bulunan ve gündelik pratikler biçiminde dışavurulan popüler kültürün önemi belirgindir. Popüler kültür Fiske'in (1989: 1) belirttiği gibi kültürün yapımıyla ilgilidir; kültürün yapımı ise toplumsal bir süreçtir. Öznellik, toplumsal ilişkiler, söylemler ve metinlerin anlamları toplumsal sistem içerisinde gerçekleşir. Bu anlamlar ve söylemler, mikro ve makro düzey ilişkileri oluşturan farklı pratik ve deneyimler aracılığıyla yeniden üretilir. Böylelikle, toplumsal sistemin devamlılığı sağlanmış olur. Bu pratik ve deneyimler kültürel yapının mikro bileşenleridir ve bu bileşenlerin toplumsal dolaşımı da yine kültürel sistemi gerektirir. Her toplumsal sistem kendi sistemik sürdürülebilirliğinin sağlanması ve gerektiğinde toplumsal sistemin manipülasyonu amacıyla kültürel anlamlar sistemine ihtiyaç duyar. 
Toplumsal sistemin yeniden üretimi, maddi altyapı kertesi dışında, kültürel üstyapının varlığını zorunlu kılar. Örneğin, popüler kültürün üretiminin sine qua nonu; alt sınıfların ve bağımlı grupların kendilerine toplumsal sistem tarafından sağlanan maddi ve söylemsel kaynaklar aracılığıyla gerçekleştirdikleri formasyonlardır. Bir başka şekilde ifade etmek gerekirse; toplumsal sistemin üretimi söz konusu olduğunda (üretim tarzı, ideoloji, söylem ve pratik gibi bir dizi bileşen), hâkim sınıfların kültürel süreçlerin (yeniden) üretiminde belirleyici olmaya uğraş verecekleri, sahip oldukları güç ve toplumsal nüfuzla kültür yapısını kendi çıkarlarına hizmet edecek biçimde kurumsallaştıracakları söylenebilir. Marx ve Engels'in (1996: 75-76) deyişiyle, egemen sınıflar kendi çağlarının düşüncelerinin üretimi ve dağıtımını düzenlerler. Kendi düşüncelerini tüm toplumun üyelerinin ortak çıkarıymış gibi temsil eder, düşüncelerini yegâne rasyonel ve evrensel düşüncelermiş gibi sunarlar. Örneğin, aristokrasinin egemen olduğu zamanlarda namus, onur, bağlılık vb. kavramlar egemendi. Burjuvazinin egemen olduğu zamanlarda ise özgürlük, eşitlik vb. kavramlar egemendir. Hâkim sınıf ya da toplumsal gruplar şüphesiz ki dünyayı belirli biçimlerde görür ve yönetilenlerin de kendi inandıkları şeylere inanmalarını, dünyayı benzer biçimlerde görüp yorumlamalarını isterler. Şeyleri bilme biçimlerinin olabildiğince standardize edilmesi ve toplumsal alana yayılması; yöneten sınıfların iktidar ve çıkar ilişkileri açısından hayati önem teşkil eder. Bu doğrultuda, tüm bir toplumsal yapı ve düşünce üretim süreçlerine dair strateji ve pratiklerin hayata geçireleceği açıktır. Ne var ki toplumsal sistemi yapılandıran güçlerin alt sınıfları uyumlulaştırma ve boyun eğdirme pratik ve niyetleri hareketsiz ve izole bir yapısal vakum ve bunun yol açacağı toplumsal stazla belirlenmez. Toplumsal homojenizasyondan, uyumlulaştırmadan, boyun eğdirmeden veya yönetilenlerin toplumsal iktidara dönük rızalarının üretiminden bahsedilebileceği gibi, bu süreçlerin dayatıldığı, sosyalizasyon süreçleri yoluyla benimsetildiği tekil, kolektif öznelerden ve bu öznelerden, yani tabandan gelebilecek olası dirençlerden bahsetmek de zorunludur.

Toplumsal hiyerarşiler ve güç ilişkileri bağlamında bakıldığında, kültürü üreterek onun kurumsallaşmasını sağlayacak güç ve etkinliği elinde tutmayan grupların, kendi (politik) dillerinin veya konuşma ve argüman geliştirme yeteneklerinin sınırlı olduğunu, konuşsalar dahi yankı bulmayacağını, yankı bulsa da madunların bunu iktidarın konuşma ve bilgi ekonomisinden bağımsız olarak tasarlayıp gerçekleştiremeyecekleri öne sürülebilir. Gelgelelim; bunun sonucunda hâkim bilme ve görme biçimlerini yeniden üretilerek kurumsallaştıracağını söylemek mümkün olacaktır. Hâkim grup-bağımlı grup ilişkisi ekseni üzerinden yapılacak bu tür bir tahlile paralel olarak "madunların özneolmayan bir özne olarak vücut bulduklarını; konum-olmayan bir konumu işgal ettiklerini" (Spivak, 1988: 276) söylemek de yine aynı şekilde mümkündür. Bu durum, madunların kendi kimlik ve temsillerini kendi yöntem, araç ve pratikleriyle (eleştirel, tartışmacı ve en önemlisi de kurucu biçimlerde) kodlama direnci ve yetisinden tamamıyla yoksun olduklarını söylemenin bir başka yoludur. Yönetilenlerin konuşmaya muktedir olmadıkları, kendilerinin dışında olanları çağırsalar dahi seslerinin duyulamayacağını varsaymak; toplumsal düşünce tarihinin üzerine kurulduğu yapı-özne karşıtlığını/ gerilimini yapıdan ve nesnel koşulların belirleyiciliğinden yana savlayan düşünme biçiminin bir tezahürü olacaktır. Yapının etkisini önceleyen/öne çıkaran bir bakış, süreç/öznel deneyim, karşıt-konumlanma, bilinçli insan faaliyeti ve bu faaliyetin araladığı mücadele ve tazyik alanları, biçimleri ve elbette olası ütopyaları gözden kaçırmaktadır. Böylece, toplumsal pratik var olsa da, yapının yeniden üretim süreçleri üzerine çökertilir ve bireylerin öznel kapasiteleri buharlaştırılır. Fail konumlarından uzaklaştırılan bireyler, birer otomat olarak yorumlanır. 
Özneyi insan iradesini edilginleştiren, yok sayan bu tür bir konumlanmaya karşın, alt sınıfların bağımlı olma hallerini keşfederek, bu halleri anlamaları ve anlamlandırmaları için gerekli çıkış yollarının takip edilmesi zorunludur. Bu tür bir çaba ya da özneye failliğini iade eden karşı çıkış örneklerinden biri de maduniyet-boyunduruk ilişkisini Güney Doğu Asya toplumları ekseninde tartışan Hintli tarihçi Ranajit Guha tarafından gelmiştir. Guha'ya (Guha 1988'den aktaran Ergene, 1999/2000: 33) göre madunların tarihsel süreçte duyulmayan seslerini duyulur kılmak için, madunluk durumlarını bastıran elitlerin formüle ettikleri belgeler ve kültürel temsil biçimlerine yakından bakılmalıdır. Çeşitli vakaların analizleri yapılmalı, bu belgelerden hareketle madunun kimliği görünür kılınmalıdır. Guha'nın iddiası, bir karşıt-dengeleyici olarak, toplumsal güç dengesini- görece de olsa- madunların lehine çevirir gibi durmaktadır. Fakat bu yanıltıcı olabilir; Guha temel olarak madunluk durumunun bilgisinin teknik uzmanlık ve yetkinliğe sahip eşik bekçilerince (buradaki kullanımıyla entelijansiya) ortaya çıkarılabileceğini ima etmektedir. Bunu somutlamak gerekirse; Hintli tarihçi bir başka yerde Hindistan ulusalcılığının elitist-kolonyal, burjuva-elitist düşünce hattı eliyle yazıldığını söylemiş, 19.yüzyılda Kolonyal Hindistan'da görülen köylü ayaklanmalarının elitist tarihçilerce ele alındığını, bu manada, bu profesyonellerin olayları yorumlama tarzlarının yanlı olduğunu göstermiştir.

Elitist (Batılı) tarihçilerin oluşturdukları tarih ekolü, kendi karakteristik özellikleri nedeniyle, Hint köylü sınıflarının içerisinde bulundukları maddi koşullar ve bu koşullara karşı sergiledikleri isyanları açıklamak için doğru perspektifi sağlayamaz. Guha'nın (Guha 1983'den aktaran Biswas, 2009: 201-202) öne sürdüğü gibi bunu yerli yerinde yapabilecek ve kendi içinde halkın kendi öz iradesiyle ortaya koyduğu politik eylemliliği anlayıp açıklayabilecek 'özerk' bir ekolün oluşturulması gerekmektedir. Guha bu varsayımıyla eşik bekçilerinin madun kimliğini işaretleyen temsilleri ve ideolojik söylemleri açımlayarak, madun olma kimliğinin özsel olarak açığa çıkarılabileceğini savunmaktadır. Bununla öne sürülen tarih yazımı; aşağıdan, aşağının kendi epistemolojik süreçleri ve kendi söz dağarcıkları yoluyla değil, profesyonel uzmanlık, yorum bilgisi ve etik ilkelere sahip bir grup ayrıcalıklı insanın yerine getirebileceği bir faaliyet olarak kodlanmaktadır. Guha bu sözleriyle, daha çok, kendi kişisel akademik çalıșmaları yanı sıra, 1980 yılı sonrasında oluşturulan "Maduniyet Çalışmaları" yazını ve kolonyalist baskı ve sömürüyü temel sorunsalı olarak kabul eden "Maduniyet Çalışmaları Grubu"na işaret etmektedir. Maduniyet yazını her ne kadar madun grupların hikâyelerini anlamaya, ezilenlerin güç yapılarıyla başa çıkma strajilerini ortaya koymaya dönük önemli bir çaba olsa da madun grupların içerisinde vücut bulmak zorunda bırakıldıkları bağımlılık söylemini yeniden üretmekte, bu söylemi doğallaştırmaktadır. Böylelikle, toplumsal gerçekliği seçkinlerle süregiden bitevviye müzakereler, mücadeleler içerisinde üreten, devindiren toplumsal grupları gerçekliğin üretiminde entelijansiyaya bağımlılaştırmanın yolları meşrulaştırılmaktadır. Ne var ki bağımlılık söylemine dönük karşıt okumalar getirmeksizin, alternatif anlam üretimi süreçlerinde bulunmaksızın, iktidarın kapatıcı ve tekçi bir normatif gerçeklik iddiasıyla donanmış lafzını etkisizleştirmek mümkün olmayacaktır.

Madun grupları çağırarak onları toplumsal özneler olarak kuran ideolojik telkinlerin kendisini aşağıdan gelecek dirençlerle karşılaşmaksızın yeniden üretemeyeceği gerçeği ıskalanmamalıdır. Çünkü yönetici sınıf niyet ettiği/hedeflediği kültürlenme ve sosyalizasyon işlevinin karmaşık bir süreçle mürekkep olduğunu; bu işlevi yerine getirirken kullandığı mesajların toplumsal iletişim ya da alt sınıfların niyetleri ve 
çıkarlarıyla örtüşmeyeceği intimalini her zaman için hesaba katmak durumundadır. Hall'un (1981) dediği gibi popüler kültür iktidar bloğu ve madunlar arasında görülen karşılıklı ilişsiler sonucunda yapılandırılır. İktidar bloğu farklı toplumsal güçlerin ekonomik, hukuki, ahlaki ve estetik ittifakları sonucunda oluşan, görece bütünsel, birleşik ve yine görece istikrarlı denebilecek ilişki ve mekanizmaları ifade eder. Diğer yandan, madunlar ise çok çeşitli, kendi içinde savruk ve toplumsal alan boyunca dağınık denebilecek bir özneyi gösterir. Madunlar sürekli inşa edilen ve reforme edilen bir dizi toplumsal bağlılıkla vücut bulur. İktidar-yönetilen ilişkisi homojen bir yapıyla heterojen bir yapı arasında cereyan eder. İktidar bloğu toplumsal farklılıkları kontrol etmeye, yapılandırmaya ve minimize etmeye çalışarak, kendi çıkarlarına hizmet edecek bir toplumsal formasyonu sağlamaya meyillidir.

Heterojenlik gösteren madun gruplar ise toplumsal farklılıklarıyla öne çıkar ve bu farklılıkları çıkarlarının da çeşitlenerek ayrıksılaşmasıyla sonuçlanır. İktidar bloğu kendi çıkarlarını gerçekleştirmek amacıyla toplumsal sistemi düzenleyip onu sürekli olarak yeniden üretmek zorundayken; alt sınıfların ve bağımlı grupların böyle bir zorunlulukları bulunmaz. İktidar onlardan kendilerine dönük yapılan ideolojik çağrılara yanıt vermelerini, yönetilebilir toplumsal birimler olarak hareket etmelerini bekler. Bunun için, toplumsal sinir yapısını kontrol edip düzenleyebilecek hiçbir ideolojik süreç ve aygıtı devreye sokmaktan çekinmez.

Hâkim sınıftan veya toplumsal gruplardan toplumsal alana doğru yayılan ideolojik bir çağrının yerini bulabilmesi, bu sınıfların kendi fikirlerini hâkim ideoloji olarak toplum içerisindeki bireylere benimsetebilmesiyle ya da bir diğer deyişle, bireylerin iktidarın çağırma pratiklerine olumlu yanıt vermeleriyle olur. Marx'ın (1996: 76) tespitiyle söylemek gerekirse, burada temel olan; hâkim sınıfın maddi gücü doğrultusunda zihinsel alana hâkim olmasıdır. Buradan hareketle Oskay'ın (2000: 236) da belirttiği gibi aile, okul, iş, çalışma yerleri ve/ya kitle iletişim araçları hep birden hegemonik ideolojiyi oluşturacak biçimde uyumlu ve çatışkısız bir işleyişle toplumsallaşma araçları olarak işletilmelidir. İktidar, kontrol ve denetimi altında bulundurduğu sofistike ideolojik aygıtlar sayesinde- burada not etmekte fayda var ki devlet, gerektiğinde, mahkemeler, ceza sistemi ve polisiye güç gibi baskı aygıtlarını da harekete geçirebilir- gündelik yaşam pratikleriyle yeniden üretilen kültürü, kendi değer ve inançlarıyla uyumlu anlatılarla konumlandırmaya uğraş verecektir. Fakat bununla birlikte üretilen içeriklerin beklenen türde bir toplumsallaşma süreci doğuracağı hiçbir zaman a priori değildir. Sürecin kendisi kaygan, olumsal ve süreklidir, sürekli olmaya yazgılıdır. Sonuçları açısından bakıldığında ise başarısı asla ön görülemez ve garanti edilemez.

Her şeyden önce modern toplumlarda kültürel üstyapıya koltuk değnekliği yapan ya da bu amaçla tasarlanan ve toplumsal olarak dolaşıma sokulan popüler kültür; sadece kültür endüstrilerinin rasyonel kitlesel üretim ve dağıtım şebekelerinden oluşmaz. Hall'un (2001: 166) ifade ettiği gibi kültür üretimi teknik ve profesyonel olmak üzere bir dizi süreç ve canlı insan pratiğinin dolayımı içerisinde gelişir. Üretim süreci siyasal, ideolojik ve toplumsal pek çok değişkenin etkisine açıktır. Bu manada, toplumsal kültür hegemonya mücadelesinin önemli bir parçasıdır. Gramsci'ye (1971: 145-146) göre hegemonya, hâkim sınıfın farklı sınıflarla veya sınıf fraksiyonlarıyla oluşturduğu ittifakları anlatır. Hâkim sınıf bu ittifaklarla birlikte toplumu basitçe yukarıdan yönetmez, toplumsal gruplar ve yönetilenler üzerinde uygulayacağı ahlaki ve entellektüel liderlik 
yoluyla onları kendi yönetimi altında eklemler. Sabit bir durumdan çok ucu açık bir süreci ifade eden hegemonya, hâkim sınıfın herkesin çıkarınaymış gibi sunduğu belirli düşüncelere karşı toplumsal rızanın üretimini gerektirir. Rıza üretimi alt sınıfların baskın güç ilişkilerinin ifadesi olan değerler, idealler, amaçlar, kültürel ve politik anlamları desteklemesine, yöneten sınıfın değer ve anlam sistemine taraftarlık etmesine yardımcı olur. Bu doğrultuda, hegemonik projelerin gerçekleșebilmesi, üretim ilişkilerinin inşası ve toplumsal meşruiyeti kadar ideolojik kontrol işleviyle de ilişkilidir. Hegemonya ve ideoloji birbirinden ayrı iki kavram olarak görülemez. Çünkü hegemonya "egemen ideoloji aktarımı, bilinç biçimlendirmesi ve sosyal iktidar deneyimi aracılığı ile işleyen bir süreçtir" (Lull, 2001: 19). Popüler kültür, egemen ideolojinin aktarılmasına, egemen kodların gündelik yaşam pratikleri ve gündelikli bağlamlar içerisinde sinsice, görünmezleşerek toplumsal bilinç yapısına aktarımını sağlayan bir mekanizmadır. Gelgelelim ki hegemonya mücadelesinin toplumsal çatışmayı ve yenişme mücadelelerini içereceği de açıktır.

Burada, popüler kültür, Storey'in (2009: 81) belirttiği gibi kültür endüstrilerinin toplumsal iletişime dâhil ettiği kültürel metinler ve pratiklerle olan tüketim ilişkileri sonucunda ürettikleri bir şeydir. Dolayısıyla, hegemonyanın kurulumasında egemen kodları taşıyıp yeniden üreten popüler kültür ürünlerinin ya da bir bașka deyișle, ideolojik biçimlerin toplumsal gruplar, alt sınıflar tarafından pasif bir biçimde alımlanmayacakları, aksine, bu biçimlerin olası mukavemetler ve karşıt anlam üretimiyle karşılanacağı söylenebilir.

Fiske (1996: 236), hâkim sınıf tarafından üretilen kültürel metinlerin 'popüler' olabilmesi için bu metinlerin halktan gelen, halka ait olan sanata, baskı ve egemenliğe karşı savaşan halk kesimlerine yani 'popüler güçlere' dayanması zorunludur demiştir. Kültürel metinler hedef alımlayıcısına seslenecekse başat ideolojinin sesini içermek zorunda olduğu gibi, alt sınıfların muhalif toplumsal konumlarına göndermede bulunan göstergeleri de içermelidir. Bu tür çelişkiler olmazsa hedef alınan okurlar kendilerine seslenildiğinin farkına varamayabilir. Bunun sonucunda, çağrı reddedilerek iletişim gerçekleştirilmemiş olur. Kültür üretimi, tüketim uğrağı olmaksızın tamamlanmaz ya da kendi toplumsal çevrimini tamamlayabilen bir hareket yasası içerisinde şekillenmez.

Toplumsal iletişim içerisinde mübadele edilen mesajların anlamları sabit değildir, bir örnek görülemez. Örneğin, Lentrichchia ve McLaughin'in (1995: 332) belirttikleri gibi bir popüler kültür metni olarak Rambo filmi seçici bir biçimde ele alınıp toplumsal dolaşıma sokulmaksızın potansiyelini gerçekleştirmiş değildir. Metinler toplumsal olarak konumlanmış tüketicilerce kullanılmaksızın sahip olduğu metinselliği tamamlayamaz. Kültürel anlamlar veya medya dolayımlı mesajlar metne hâkim düz ve yan anlamlar alımlanamak yorumlanmaksızın kendi söylemsel üretimini sonlandırmaz. Hall'un ünlü "Kodlama-kodaçımlama" çalışmasıyla ileri sürdüğü gibi tam anlamıyla saydam, kendi içinde kapalı bir iletişimden bahsedemeyiz. Çünkü klasik tek yönlü gönderici-mesaj-alıcı şematiği yanılsamalıdır. Bunun tersine, mesajın karmaşık ve birbiriyle ilişkili fakat yine de analitik olarak ayrı duran üretim ve tüketimleri söz konusudur. Buna göre, toplumsal iletişimi gönderen-mesaj-alıcı döngüsü içerisinde kavrayan bir yaklaşım yerine, iletişim sürecinin Marx'ın "Grundrisse" ve "Kapital"de (2006: 163) ortaya koyduğu meta üretimi modelini andıran farklı uğraklarla anlaşılması daha doğru olur. Mesajın toplumsal iletişim döngüsü; üretim, dolaşım, dağıtım/tüketim ve yeniden üretim uğraklarıyla birlikte düşünülmelidir. Bu açıdan bakıldığında, mesajın tüketim uğrağında uğradığı 
kırılma ve sapmaların yerli yerine konulması gerekir. Kültür endüstrilerinin ürettikleri mesajlar toplumsal olarak dolaşıma girer ve farklı dolayımlayıcı teknolojik araçlar yoluyla tüketim uğrağında konuşlanır. Mesajın tüketim uğrağında alımlanmasıyla birlikte farklı içerimlere yol açarak yeniden üretilmesi her zaman olasıdır.

Üretim ve tüketim süreçleri Hall'un (1997: 63-66) kendi terminolojisiyle bakıldığında kodlama/şifreleme (encoding) ve kod açımlama/şifre çözümü (decoding) pratikleriyle açıklanabilir. Tüketim uğrağı, Hall'un gösterdiği gibi genel iletişim süreci içerisinde izleyicilerin farklı okumalarda bulunabildiği anlara işaret eder. Buna göre, izleyiciler mesajlar karşısında üç farklı okuma türü geliştirir. Bunlar "hegemonik", "müzakereci" ve "muhalif" okumalardır. Hegemonik okuma yapan bir izleyici mesajı önerilen anlamına uygun biçimde okur. Bu saydam bir iletişim için ideal bir okuma türüdür. Bu durumda, profesyonel kod tarafından oluşturulan pozisyon ile izleyicinin pozisyonu örtüşür. Profesyonel kod hâkim kodun hegemonyası çerçevesinde çalışır. Hâkim tanımlar oldukça hegemoniktir çünkü küresel anlamda hâkim pozisyonda olan olayları ve durumları temsil eder.

İkinci okuma biçimi olan müzakereci tarzda gerçekleşen bir kod açımlama pratiği ise hem benimsenen hem de reddedilen unsurların birleşiminden oluşur. Hall buna örnek olarak grev yapma hakkını sınırlayan yasa tasarısı ve bunun sonucunda ücret artışının durdurulması riskiyle karşı karşıya kalan işçinin verdiği tepkiyi gösterir. Ekonomik tartışmalar söz konusu olduğunda kod açıcı hegemonik tanımlamayı benimseyebilir ve herkesin enflasyonun düşmesi için daha az kazanması gerektiğini kabul edebilir. Ancak bu pozisyonu benimsemesi daha iyi bir ücret ve çalışma koşulları için grev yapmasını da engel değildir. Dolayısıyla, verili mesajın anlamları kesin olarak reddedilmez, fakat bu mesajın muhalefet edilecek unsurlar taşımadığı anlamına da gelmez. Son olarak kod açımlamanın muhalif biçimlerde görüldüğü durumlar da bulunur. Muhalif okumada izleyici metnin içerdiği bütün anlam ve yan anlamları çözer ve bunlara karşı tutum alır. Hall buna televizyonda maaş artışı üzerine yapılan bir tartışmayı izleyen kişinin ulusal çıkarlar olarak temsil edilen mesajları sınıf çıkarları şeklinde okumasını örnek gösterir.

Kodlama ve kod açımlama, yani mesajların üretim ve tüketim uğraklarıyla olan ilişkisi popüler kültürün en önemli aksiyon türü örneklerinden Rambo filmiyle de somutlanabilir. Amerika'nın psikolojik savaş stratejisinin ve kültürel hegemonyasının önemli taşıyıcılarından biri olan Rambo serisi ilk kez 1982 yapımı İlk Kan filmiyle gösterime girmiştir. Beş filmden oluşan seri 2016 'da vizyona giren Son Kan filmiyle son bulmuştur. Rambo filmine dönük olası izleyici konumları şu şekilde varsayılabilir: İlk olarak, alımlayıcılar üretim süreciyle birlikte metne ideal olarak iliştirilen ideolojik telkinlere farklı biçimlerde eklemlenecektir. Kimi grup izleyiciler belirli bir dramaturji ve estetik rejimiyle birlikte ilerleyen bu telkinlere kendi kişisel yaşam hikâyeleriyle bağlanarak tutunacaktır. Bir başka grup izleyici ise Rambo imgesiyle özdeşleşerek Amerika'nın soyunduğu, seslendirdiği "dünya barışı, demokrasi ideali, özgürlüklerin tesisi” benzeri söylemleri ve bu söylemlerin içerisinde eridiği genel politik ajandayı onaylayacaktır. 


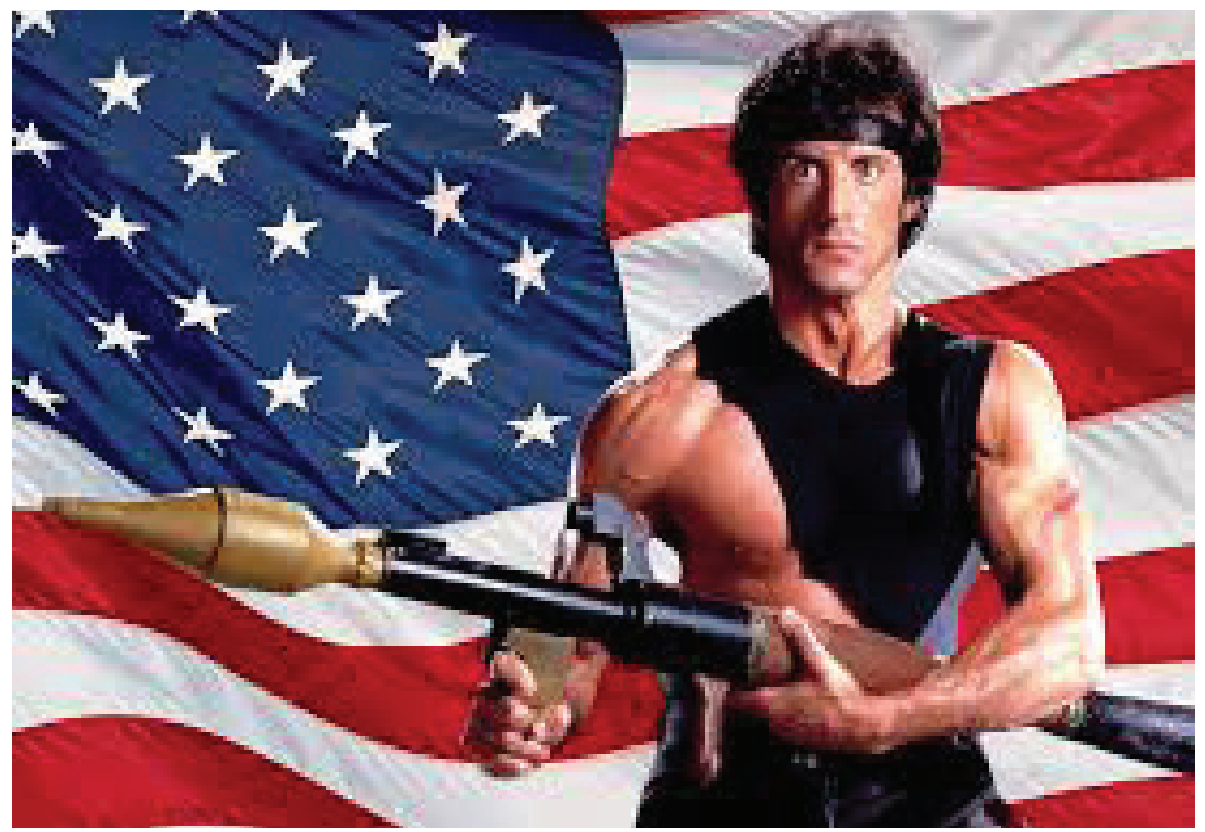

Resim 1. Serinin hâkim mesajını en iyi anlatan görsellerden biri olarak savaşçı Rambo imgesi

Son olarak, farklı grup izleyiciler metnin kendilerine sunduğu kriz ve çatışma anlarına, bu anlarda yüzeye çıkan çelişkilere ya da bu çelişkileri temsil eden karşıt, antikahramanlara dikkat kesilecektir. Böylece, metinde yaşanan kopma ve kırılma anlarında kendi gündelik yaşamlarındaki çelişki ve sorunları fark edecektir. Dolayısıyla, kültür üretimi, üretim ve dağıtım süreçlerince olduğu kadar; öznel kullanım/tüketim pratikleri içerisinde de şekillenir. Anlam üretimi özneler arasılığı ve anlamın geniş bir semiyotik çevrim içerisinde diğer anlamlarla olan ilişkisini işaretleyen kolektif bir süreçtir. Bu durum öznelerin kendi anlam dünyalarından, beklenti, ilgi ve çıkarlarından da toplumsal iktidar ilişkilerinden de izole ya da bağımsız değildir. Yapı ve özne denebilecek bu iki öğe arasında karşılıklı etkileşim, gerilim, uzlaşma, kısacası etki söz konusudur.

Fiske’e (1989: 8) göre popüler kültür gündelik yaşam ile kültür endüstrileri ürünlerinin kesişiminde halk tarafından oluşturulur. Kültür onlara basitçe dayatılamaz. Toplumsal kesimlerden doğacak olası mikro mukavemetler her zaman hesaba katılmalıdır. Bu mukavemetlerin doğası temelde Fiske'in kaçınma (evasion) ve direniş adını verdiği pratiklerle açıklanabilir. Fiske (1989: 9-10) kaçınma eylemi ile öznelerin, ideolojik ya da fiziki toplumsal zaptan (capture) kurtulmalarını anlatır. Hâkim sınıf toplumsal hegemonyasını desteklerken, ekonomik ilişki biçimlerini kendi lehine olacak şekilde konsolide eder ve kurar. Yine kendi iktidarına destek ve taraftar bulabilmek için semiyotik iktidara, yani anlam üretme gücünden de yararlanmak zorundadır. Buna karşın hâkim anlamları reddeden, bu anlamlardan kaçınmayı içeren semiyotik direniş, aynı zamanda, yönetilenlerin yeni anlamlar üretmeleriyle bağlantılıdır. Hâkim anlamların aksine kendi muhalif anlamlarını inşa eden madunlar, toplumsal çıkarları için hayati rol oynayacak şekilde, iktidarı yeniden dağıtır ve gücün dağıtım dengesini kendi avantaj 
ve çıkarlarına olacak biçimde bozar. Madun grupların farklı biçimlerde düşünmeleri, toplumsal bireylerin öz varlıkları ve toplumsal ilişkilere dair anlamları yeniden inşa etmeleriyle sonuçlanabilir. Bu politik eylemin öncülünü oluşturur. Politik stratejilerin başarı kazanması da buna bağlıdır. Madunların hâkim sınıfın ideolojik mesajlarını taşıyan popüler kültür metinlerini niyet edilen ideolojik anlamlarından saptıracak şekilde okuması önemlidir. Fakat bu tek başına yeterli değildir; ideolojik mesajların muhalif okumalarla ters yüze edilmeleri süreci alternatif anlamların imaliyle sürdürülmelidir. Muhalif okumalar farklı anlamların, madunların kendi çıkarlarını ifade eden semiyotik çerçevelerin üretimi olmaksızın yetersiz kalacaktır. Madunların toplumsal söyleme dönük müdaheleleri, karşıt politik dağarcığın var edilebilmesi ve doğrudan eylem yoluyla siyasal katılıma dönüştürülebilmesi için gerekli ve kaçınılmazdır.

Bireyler popüler kültürü kendi öznel kullanım/tüketim biçimleriyle yeniden üreterek, bu içerikleri kendilerine mal edecek yaratıcılık becerisini taşır. Birey gündelik yaşamı boyunca maruz kaldığı ideolojik endoktrinasyonun etkisine karşın, kendi özerk okuma/ yorumlama/tüketim pratiklerini gerçekleştireceği kaçış çizgilerine sahiptir. De Certau'nun "Gündelik Hayatın Keşfi-1" (2009) başlıklı çalışmasında ortaya koyduğu gibi, modern toplumlarda kültür endüstrileri aracılığıyla imal edilerek toplumsal bireylere dayatılan sembolik anlamlar, bireyin gündelik yaşamı içerisinde benimsediği farklı kullanımlar, tüketim alışkanlıkları ve kültürü kendi öznel pratik ya da intiyaçlarına göre mal etme biçimleriyle dönüşmeye meyillidir. De Certau bu noktada sıradan insanın toplumsal alanın bütününe yayılarak merkezsizleşen iktidar uygulamalarıyla yani "stratejiler"le başa çıkmada sergilediği mikro dirençlerin önemine değinir. Bunlar aşağıdan gelen dirençler, yani "taktikler"dir. Taktikler zayıf olanın güçlüye karşı elde ettiği başarılardır. Zayıflar bu başarıları elde ederken kendilerince dolaplar çevirir, oyunlar oynar, avcılara özgü hilelere başvurur ve tuzaklar kurar. İşleri el çabukluğuyla kendi lehine çevirmeye, iktidarın güç kullanımını elindeki araç ve imkânlarla hedefinden saptırmaya çalışır. Taktikler- merkezsizleşerek toplumsal alana yayılan iktidar stratejileri gibi- yerel dengelerın dağılmasıyla parçalara bölünmüş, çevreye saçılarak çoğalmıştır.

De Certau (2009: 105-116) strateji ve taktik kavramlarına "okuma/görme eylemi" ile de ilişkilendirir. Fransız düşünüre göre çağdaş kültürün koşulladığı ve yazı karşısında öncelediği okuma/görme eylemi, televizyondan yazılı basına, reklamdan pazarlamadaki tüm kutsallık tezahürlerine tesir etmiştir. Gerçeklik kendi gösterimine ya da gösterme kapasitesine indirgenmiş, iletişim gözün dolaşım sınırları içerisine hapsolmuştur. Günümüzde giderek yaygınlaşan bu yeni ikileme göre yanlızca bir yazma-okuma eyleminden bahsetmek mümkündür. Bu, gösteri toplumunda gözetleyiciye dönüşen tüketici için tanımlanmış pasifliğin geldiği son noktadır. Herşeye rağmen okuma eylemi kendi içinde "sessiz bir üretimin" tüm özelliklerini barındırmaktadır. Okuyucu sayfaları türetir, gezgin ve gözetleyici gözü sayesinde metni dönüştürür. Birkaç sözcükten çıkarttığı anlamlar yazılı uzamı atlar. Okuyucu, geçici bir ritim duygusuyla sayfa üstünde dans eder ve bu şekilde başkasının metnini yeniden benimseyerek ondan zevk alır.

Metinde düzenbazlık yapar ve onu kurnazca dönüştürür, metni yaptığı eklemelerle belleğinde yeniden kurar. Okunan, belleğe alınana dönüşür. Okuyucu ya da tüketici metni kiralık bir daire misali üzerinde oturulan bir mekân şeklinde yeniden örgütler, mekân oradan geçmekte olan biri tarafından kiralanarak geçici de olsa sahiplenilen bir yer olur. De Certau'nun okuma eylemi bağlamında söylediklerinden hareketle 
bakıldığında popüler kültür, tüketicisi/alımlayıcısı tarafından pratik edilen yaratıcı okuma ve yorumlama pratikleriyle mürekkep olabilir. Hâkim sınıfın halk kesimlerini kendi egemen söylemi altında eklemleme çabası her zaman için okuma eyleminin izafi doğasına çarpıp hedefinden sapma potansiyeli taşır. Niyet edilen alt metinler çoğu zaman niyet edilmeyen geri bildirimlere, tutum ve davranışlara yol açar. Atipik ya da beklenmedik olana denk düşen bu ve benzeri dirençler gündelik hayat içerisinde peyda olur. Fransız Marksist düşünür Guy Debord'un (2002: 239) öne sürdüğü gibi tüm projeler gündelik yaşamın içerisinden fışkırır; onun içerisinde kök bulur. Gerçek başarısını ve vücut buluşunu yine aynı düzlemde yani gündelik yaşam üzerinde gerçekleştirir. Güçsüzler egemenlerin ürettikleri ve toplumsala yaymaya çalıştıkları hâkim kültüre karşın, kendi varolma tarzlarını sergiler ve bu tarzları cisimleştiren öznel pratiklerle yaratımlarda bulunur. Değişkenlik gösteren öznel kullanım/tüketim biçimleri iktidarın niyet etmediği, öngörmediği ya da hesaplamadığı sonuçları doğurmaya gebedir. Egemen okuma ve yorumlama biçimleri, tüketici olarak kodlanan ve pasifize edilen toplumsal kesimlerce farklı biçimlerde üretilir. Bu, bireylerin farklı öznellikleri (kültürel, sınıfsal, dinsel, etnik aidiyet ve toplumsal cinsiyet benzeri) ve bunun bir yansıması olan kişisel ilgi, haz, beğeni, alışkanlık ve tüketim tarzlarıyla mümkün olur. Kültür üretimi hâkim sınıfların üretici egemenliğinde fakat bağımlı sınıflarla karşılıklı yürütülen açık/örtük müzakereler, farklı okumalar, yorumlama süreçleri ve öznel kullanım tarzları benzeri toplumsal üretimlerin sonucunda gerçekleşir.

\section{Sonuç}

Yapı ve özne gerilimi gündelik hayatın içinde, onun dolayımıyla hayat bulur. Gündelik hayat ise kaçınılmaz biçimde şimdiye ve buradalığa demir atar. Kültürel biçimlerin görünür olabilmesi için gerek duyduğu bağlam ve öznel/kolektif deneyimler, gündelik hayata, sıradan ve tanıdık olana işaret eder. Gündelik yaşam kuşatıcı ve bu anlamda her an her yerde olması nedeniyle görünmez hale gelir. Ne ki bu içinden çıkılmaz bir totalite değildir; durum tersine çevrilebilir. Kültürü, kültürel deneyim ve ifadeleri görünür, duyulur kılmak için gözleme başvurulabiliz. Kendisi de kültürel bir pratik olan gözlem, gündelik yaşamın sıradanlığını ve rutinliğini dağıtacak özenli bir geri çekilme ve dikkatli bir bakma eylemiyle gerçekleşir. Bunun sonucunda, farklı ama son kertede ortaklaşan, birbirine benzeyen deneyim ve eğilimlerin şifresi kırılarak, somut akademik çalışmalara taşınmış ve anlamlandırılmak üzere kaydedilmiş olur. Yine böylece, bağımlı olanların gündelik yaşamları ve bunun içerisinde açığa çıkardıkları ilişkilenme, kavrayış ve hissetme biçimleri ve toplumsal deneyimleri, deneyimleyenlerin kendi söz dağarcıkları ve yorum bilgileri eşliğinde görünürlük bulmuş olur.

Popüler kültür ideolojik biçimler olarak görülebilir. Popüler kültür metinleri ideolojik imajları ve yorum çerçevelerini taşır ve toplumsala dağıtır. Bu biçimler toplumsal semiyotik sistemin parçalarını, tamamlayıcı öğelerini oluşturur. Popüler kültür ürünleri hâkim semiyotik kodları toplumsalbilinç yapısına aktaran, bu anlamları dolayımlar. Popüler kültür ürünleri temelde egemen ideolojinin ifadeleridir. Gerçekliği olduğu gibi temsil etmez; onu kırarak çarpıtır. Bu metinler her zaman için ideolojik söylemlerle yapılandırıır ve ne yansız ne de tarafsızdır. Bize şeylerin doğasına dair belirli açıklama çerçevelerini sunar. Öte yandan, kültürel ürün ve pratikler aynı zamanda kolektif yorum bilgisinin üretildiği bir alandır. Bu alan karşılıklı müzakere, değiş tokuş ve olası karşıt anlam ve pratiklerle devinir. Anlamlama politikaları dünyayı görme ve 
görüleni meşrulaştırma, onu doğalmış gibi sunmaya hizmet eder. Bu anlamlar ve değerler egemen sınıfın yönlendirme ve manipülasyonlarıyla kurumsallaştığı gibi, yönetilenler tarafından müzakere edilebilir. Karşıt anlamlama pratiklerini doğurarak toplumsal gerilim ve mücadelenin fitilini ateşleme potansiyelini taşır. Bu manada, kültür ürünleri salt toplumsal kesimlere yukarıdan dayatılan metinler olarak görülemez. Bu metinler tüketim uğrağında farklı izleyici konumları ve gündelik kullanımlar içerisinde kırılmalara uğratılır. Bu nedenle izleyici, bu araştırma kapsamında Kültürel Çalışmalar ve "izleyicinin aktifliği" tartışmalarıyla gösterildiği gibi, kendisine verilen anlamları doğrudan soğurmaz, egemen anlamlar ve ideolojik manipülasyonlar karşısında sersemleşen pasif varlıklar olarak görülemez. Her zaman için üretici olabilir ve kültürün ortak yapımına katılır.

Popüler kültür alanı ve kültürel mesajlar gündelik hayat bağlamları içerisinde tüketilen hegemonik anlamlarla yapılandırılmıştır. Bu anlamlar hâkim sınıfların her yeni gün ve bağlamda şekillendirmeye, kontrol ve denetim altına almaya uğraş ve özen gösterdikleri toplumsal sistemin semiyotik güç mekanizmalarıyla desteklenmesine yardımcı olur. Semiyotik güç ve mekanizmalar, alt yapı-üst yapı dikotomisi içerisinde konuşmak gerekirse, alt sınıfların içerisinde yaşadıkları maddi koşullara rıza göstermeleri ve rızalarının yeniden üretilmesinde kaldıraç görevi görür. En nihayetinde, popüler kültür ürünleri belirli sınıf ve hâkim toplumsal grupların ideolojik değerlendirmelerini toplumsal alana taşıyan, egemen iktidar ilişkileri içerisinde inşa edilen ürünlerdir. Gelgelelim ki popüler kültürün içerisinde ve onun dolayımıyla gerçekleşen bir anlamlama sisteminin öznel kaçınma ve direnç/direniş pratiklerinden bağımsız olarak düşünülmesi olanaksızdır. Popüler kültür ürünleri egemen sınıfların hâkim anlam ve değerlerini içereceği gibi, bu anlam ve değerlerin sapma, bozulma, kırılma noktalarının açığa çıkabildiği kodları da içerir. Popüler kültür hegemonya mücadelesinin orta yerinde yer alır ve hâkim mesajların niyet edilen imlerinin saptırılmasıyla yeniden biçimlenir.

Toplumsal bireyler ve kolektif gruplar hâkim anlamların seslendirdiği ideolojik telkinlere yanıt vermekten kaçınabilir. Yanıtlar her zaman olumlu olmayabilir. Toplusal gruplar kendi karşıt anlamalarını üretebilir ya da bu mesajlara kapalı olabilir. Her ne kadar toplumsal iletişim güç ilişkileri içerisinde yapılaşmış pratik ve kurumlar tarafından üretilseler de, üretimin kendisi dolaşım/tüketim ve yeniden üretim süreçleri olmaksızın gerçekleşmez. Tüketim uğrağı hegemonik mesajlarla uyumlu okumalar yaratabileceği gibi, müzakereci ya da karşıt okuma tarzlarıyla da okunabilir. Bu mesajların maksat edilenin dışında anlamlarla karşılanabilir. Alımlayıcılar, ideolojik ikna ve rıza üretimine koşulan metinleri kendi öznel çıkarları, epistemolojik filtreleri, yorumlama becerileri, ilgi, beklenti ve intiyaçları doğrultusundan açımlayabilir. Karşıt açımlamalar, öznelerin toplumsal güç ilişkileri içerisinde fırlatıldıkları nesnel konumları ve bu konumların yarattığı ilişkileri ilişklieri yeniden üretmek yerine sorgulanmasına yol açabilir. Bu sorgulamalar potansiyel direnişin, karşıt politik dağarcığın ve eylem biçimlerinin mayalanması için gerekli meşru ve haklı zemini sunar. 


\section{Kaynakça}

Adorno, Theodor (2009). Kültür Endüstrisi Kültür Yönetimi. Nihat Ülner, Mustafa Tüzel ve Elçin Gen (Çeviren). İstanbul: Iletişim.

Biswas, Amrita (2009). Research Note On Subaltern Studies. Journal of Literature, Culture and Media Studies. 1(2): 200-205.

Debord, Guy (2002). Perspectives for Conscious Alterations in Everyday Life. The Everyday Life Reader. Highmore Ben (der.) içinde. Londra: Routledge.

De Certau, Michel (2009). Gündelik Hayatın Keşfi I. Lale Arslan Özcan (Çeviren). Ankara: Dost.

Ergene, Boğaç (1999/2000). "Maduniyet Okulu. Post-Kolonyal Eleştiri ve Tarihte Bilgi-Özne Sorunu: Osmanlı Tarihçiliği Için Yeni Dersler mi?" Toplum ve Bilim. 83: 32-46.

Feltski, Rita (2000). "The Invention of Everyday Life", A Journal of Cultural/Theory/Politics. 39:1431.

Fiske, John (1989). Reading the Popular, Londra ve New York: Routledge.

Fiske, John (1992). The Culture of Everyday Life. Cultural Studies. Grossberg Lawrence, Nelson Cary ve Treichler Paula (der.) içinde. New York ve Londra: Routledge.

Fiske, John (1996). İletişim Çalışmalarına Giriş. Süleyman İrvan (Çeviren). Ankara: Ark.

Ghandi, Leela (1999). Postcolonial Theory: A Critical Introduction, Delhi: OUP.

Gramsci, Antonio (1971). Prison Notebooks. Hoare Quentin ve Smith Geoffrey N. (der.). Q. Hoare ve G. N. Smith (Çeviren). Londra: ElecBook.

Guha, Ranajit (1983). Elementary Aspects of Peasant Insurgency in Colonial India. Delhi: Oxford University Press.

Guha, Ranajit (1988). Can the Subaltern Speak? Marxism and the Interpretation of Culture. Cary Nelson ve Lawrence Grossberge (der.) içinde. Londra: Macmillian.

Hall, Stuart (1981). Notes on Deconstructing 'The Popular'. People's History and Socialist Theory. Samuel Raphael (der.) içinde. London: Routledge \& Kegan Paul.

Hall, Stuart (1997). İdeoloji ve İletişim Kuramı. Medya, Kültür, Siyaset. Süleyman İrvan (der.) içinde. Süleyman İrvan (Çeviren), Ankara: Ark.

Hinds, E., Harold (2006). The Sine Qua Non of Popular Culture, Popular Culture Theory and Methodology. A Basic Introduction. Hinds E. Harold, Motz Marilyn F. ve Nelson Angela (der.) içinde. Wisconsin: The University of Wisconsin Press.

Inglis, David (2000). Culture and Everyday Life. Londra ve New York: Routledge.

Lefebvre, Henry (1995). Yaşamla Söyleşi, Sosyalizm, Günlük Yaşam, Ütopya. Emirhan Oğuz (Çeviren). İstanbul: Belge.

Lentrichchia, Frank ve McLaughin, Thomas (1995). Critical Terms for Literary Study. Chicago: Chicago University.

Lull, James (2001). Medya İletişim Kültür. Nazife Güngör (Çeviren). İstanbul: Vadi.

Marx, Karl (1996). Alman İdeolojisi. Sevim Belli (Çeviren). Ankara: Sol.

Marx, Karl ve Engels, Friedrich (2009). Ruling Class and Ruling Ideas. Cultural Theory and Popular Culture: A Reader, 4th edition. John Storey (der.) içinde. Harlow: Pearson Education. 
Oskay, Ünsal (2000). Popüler Kültür Açısından İdeoloji Kavramına Iliş̧in Yeni Yaklaşımlar, Tek Kişilik Haçlı Seferleri. İstanbul: İnkılap.

Polanyi, Karl (2001). The Great Transformation. Boston: Beacon Press.

Spivak, C., Gayatri (1988). Subaltern Studies: Deconstructing Historiography. Selected Subaltern Studies. Guha Ranajit ve Spivak C. Gayatri (der.) içinde. Delhi: Oxford University Press.

Storey, John, (2009). Cultural Theory and Popular Culture, 5th Edition. Harlow: Pearson.

Subaşı, Necdet (2004). Gündelik Hayat ve Dinsellik. İstanbul: İz.

Tekeli, İlhan (2000, Ekim). Tarih Yazımında Gündelik Yaşam Tarihçiliğinin Kavramsal Çerçevesi Nasıl Genişletilebilir?. Tarih Yazımında Yeni Yaklaşımlar Küreselleşme ve Yerelleşme içinde, İstanbul: Numune Yayıncılık

Volosinov, N. Valentin (1930/1973). Marxism and the Philosophy of Language. Ladislav Matejka ve I. R. Titunik (Çeviren). New York: Seminar Press.

Williams, Raymond (1983). Keywords. Londra: Fontana.

Williams, Raymond (1989). Resources of Hope: Culture, Democracy, Socialism. Robin Gable (der.) içinde. Londra ve New York: Verso. 